\title{
AFHVS 2020 presidential address: pushing beyond the boundaries
}

\author{
Molly D. Anderson ${ }^{1}$ (D) \\ Accepted: 4 December 2020 / Published online: 6 January 2021 \\ (c) The Author(s), under exclusive licence to Springer Nature B.V. part of Springer Nature 2021
}

\begin{abstract}
In this 2020 AFHVS Presidential Address, Molly Anderson suggests that we must push beyond the boundaries imposed by our training, institutional reward systems, political system and comfort zones in order to solve global challenges. She lists five challenges facing those who are trying to build more sustainable food systems: overcoming the technocratic and productivist approach of industrial agriculture, avoiding future pandemics, restoring degraded and depleted systems and resources, remaining united as a movement while creating collaborations with other movements, and redistributing power across food system actors so that everyone can realize their human rights, including the right to food. She describes three ways that she has found to be effective in pushing beyond boundaries: international collaborations, interactions with global social movements, and anti-racist work. She links these "moments" of opportunity back to the five challenges, and concludes with advice to young scholars.
\end{abstract}

Keywords Boundary work $\cdot$ Sustainable food systems $\cdot$ Social movements $\cdot$ International collaboration $\cdot$ Anti-racism

I have always been undisciplined and perversely proud of that. My doctorate was interdisciplinary, from the Ecology Curriculum at University of North Carolina, with a side of Latin American Studies; but I've never called myself an ecologist. I participated in a panel at the annual conference of the Ecological Society of America several years ago and was astonished by how few people were seriously addressing food systems, which I consider to be the quintessential social-ecological system - a concept with which ecologists had become enamored. Yet a succession of reports from the Intergovernmental Panel on Climate Change, the Intergovernmental Science-Policy Platform on Biodiversity and Ecosystem Services, the United Nations Food and Agriculture Organization, United Nations Environment Programme and other international sources point to agriculture as either the primary source of ecological degradation, for example, nitrates in freshwater (Mateo-Sagasta et al. 2017) and biodiversity loss (Dudley and Alexander 2017), or a significant

Presidential address presented at the 2020 annual meetings of the Agriculture, Food and Human Values Society Member-Organized Twitter Conference on July 23-25, 2020.

Molly D. Anderson

MollyA@middlebury.edu

1 Middlebury College, 202 Robert A. Jones '59 House, Middlebury, VT 05753, USA source, for example, food systems providing $21-37 \%$ of greenhouse gases (IPCC 2019).

I began to look beyond ecology for answers and inspiration regarding questions that seemed important to me. I conducted ethnographies, surveys, focus groups and systems analysis, ignoring (sometimes to my peril) many of the experts in sociology, anthropology, consumer studies, agronomy and political science. Later I learned that some of those fields were addressing the same questions that concerned me, but I was too impatient to study the disciplines systematically. I was driven by questions that slowly coalesced around food system transformation and what is required to reach more sustainable states. I realized over time that food justice and governance are central to sustainability of food systems.

The theme of this essay is that we need to get beyond the boundaries imposed on our thinking by our training, institutional reward systems, political system and comfort zones in order to address global challenges. Doing this is harder than it may seem, since we can't know what we don't know (although reflexivity will encourage us to identify where we should be dubious of received wisdom or our own certainties). Academics are often puffed up into "experts"; but one of the hallmarks of a mature scholar for me is the willingness to say, "I don't know, but that's a really interesting question". 
While there are many challenges before us today, I see at least five big ones in food systems/food movement work:

(1) Overcoming the technocratic productivist approach to agriculture,

(2) Figuring out how to avoid future pandemics while we learn to live with COVID-19,

(3) Restoring degraded and depleted systems and resources, including a stable climate, needed for future food production,

(4) Pushing back against forces that divide food movements while creating collaborations with other progressive movements, and finally,

(5) Redistributing power across food system actors so that everyone can achieve their human rights, including the right to food.

All of these challenges require approaches that are not yet mainstream, and they all require recognizing that we don't yet know how to solve the problem. That is why pushing the boundaries is essential.

Living on the boundary can be exciting but dangerous. I've walked away from secure jobs and into the void several times, in ways I would never advise another person to do. The idea of "boundary work" that contributes to environmental and sustainability science emerged in the early ' $00 \mathrm{~s}$, to describe the interface of science and policy, then increasingly to describe transdisciplinary science or the integration of different ways of knowing from scientists, practitioners, civil society and other people affected by a project. Transdisciplinarity succeeded interdisciplinarity, which is usually defined as the integration of knowledge from different disciplines, by adding other ways of knowing and the people who rely on them. In an undisciplined way, I have always tried to use concepts and methods developed in different disciplines, if they seem appropriate for answering a given question. This can fall prey to accusations of cherry-picking or superficiality, but can also be mind-expanding by forcing an examination of why a given concept or method doesn't fit, such as why the idea of "natural selection" or "survival of the fittest" is grossly wrong when applied to cultures (the Jared Diamond fallacy).... Or why the idea of creating "security" by building walls is ludicrous. Greater knowledge and security come instead from tearing down walls; and walls will always fall, sooner or later.

Looking back over my career, there are three "moments" that have helped me to push boundaries that are holding back progress on the challenges I mentioned. These have been opportunities to work with international colleagues, opportunities to interact with people from global social movements, and anti-racist work.

My first major foray into international work was the international Assessment of Agricultural Knowledge, Science
\& Technology for Development or IAASTD. I am deeply grateful to Mary Hendrickson and Bill Heffernan for recommending me as a contributor, and to the members of the Bureau, made up of equal numbers from governments and civil society including scientific institutions, for approving me. My contributions were all volunteer, unlike most others in the IAASTD, who were supported by their governments or work-places. But it was well worth it. In addition to some memorable trips to exotic places, the meetings of the IAASTD showed me how smart and passionate civil society members were in blasting away bullshit (such as future scenarios based on nonsensical economic assumptions); how insulated academics can be from conditions of life on the ground for people they are studying; and how US academics and government delegates are dead wrong about many aspects of international development. This was the first time I learned viscerally how despised my own government is when it tries to bully other countries into compliance with its ideological stances, which are often defied by all available evidence, at the same time that it demands more science-based decision-making. I made great contacts and acquired mentors through the IAASTD; and the contacts blossomed into other projects, such the recently-published book on Transformation of Our Food Systems: The Making of a New Paradigm (2020) that describes emerging trends over the decade since 2009, when the IAASTD was published, and the consolidation of support for agroecology as the most promising alternative to industrialized agriculture. An international group with which I work now, the International Panel of Experts on Sustainable Food Systems (IPESFood), has been one of the most rewarding collaborations I've ever had; and a few other IAASTD contributors from NGOs are on the panel.

The second way to push boundaries that has been meaningful in my career has been through interaction with global social movements. This has come mainly from participating in the Civil Society Mechanism of the Committee on World Food Security (CFS), which is the leading international space for negotiation of issues affecting food security and nutrition. Social movements are very different from NGOs in that they represent people who are on the frontlines of oppression and suffering directly from policies that take away their land, resources, and political voice. Food policies are matters of life and death for them; and the US has promoted some very dangerous policies in other countries, as well as policies that hurt our own people. Before working with the CSM, I was familiar with international NGOs from two years with Oxfam America and participation on some of Oxfam's international committees. But there is a world of difference between people who staff NGOs and are paid to learn about issues and go to meetings, and those who live the consequences of bad decisions. Working in the CFS taught me how powerful social movements can be when 
they stand their ground and don't give up, how courageous these people are in speaking their truth to the forces that beat them down, and how clear their analysis of global food system dynamics is. The CFS also taught me a lot about how corporate power has grown in the global food system and tried to take over democratic governance mechanisms. I have learned from social movements what food sovereignty means to them and what a hopeful liberating concept it is. Another way I'm working with social movements is through the People's Sovereignty Lab, a new space for interaction of social movements and academicians who support them. The journal Globalizations recently published a Special Forum of articles that were co-written by academics and social movement participants in the People's Sovereignty Lab.

At its best, international work, travel and interaction with social movements have shown me how narrow and stultifying the options within our neoliberal political system are, and how poorly it meets basic human needs-to say nothing of realizing human rights-compared with societies that have less inequality and adequate social welfare programs. This has sharpened my critique of the neoliberal food system and propelled a search for alternatives, whether those are in the commons, solidarity economies or mutual aid. The mantra that the US is best in the world in all possible ways has become both a caricature and abnegation of real leadership; but we need to get outside our country to see just how absurd that is, how much better off quality of life is in other countries-in everything from quality of food to healthcare to parental leave-and how much they pity us. Of course, life is far worse in many countries than in the US; but the US stands out for its arrogance, its refusal to learn from positive examples, and the contrast between what we could do with the wealth and power we have and what we actually do.

The third way to push boundaries, engaging in antiracist work, has particular relevance now as the obscene inequities in the US food system have become even more apparent with COVID-19. I am trying to understand the history and consequences of racism better with help from others (such as the impressive History of White People by Nell Irvin Painter). Anti-racist work has made a big difference in how I see the food system and how I make sense of so many things happening today that seem totally senseless. The clearest explanation to me of why the Trump Administration forced meatpackers to go back to work in crowded unsafe conditions; why it refused to allow expansion of our most successful anti-poverty and anti-hunger federal program, the Supplemental Nutrition Assistance Program; and why it refuses asylum seekers at the Southern border even when farmers desperately need their labor is sheer White supremacy. There are echoes across time with how Southern politicians resisted inclusion of farmworkers and domestic workers in the 1938 National Labor Relations Act, how the brief promise of " 40 acres and a mule" was snatched away from freed slaves, and how treaties with Indigenous people have been violated so that Whites could take the best land. Of course, this is compounded by corruption and toadying to powerful industries that support the Republican administration, but the impact is to reinforce White supremacy.

As many people have pointed out, our economic system was founded on the labor of enslaved people, and our food system with its "cheap food" objective depends on exploiting brown and black bodies. Going a bit farther, much of the resistance to accepting social, economic and cultural rights in the US is racist, in that many White people believe it would give undeserved advantages to people of color, while those same White people are wallowing in undeserved social, economic and cultural advantages of White privilege. Unraveling racism by recognizing and examining our privileges as White people is an essential first step for us, and seeking to ensure that human rights are enjoyed by everyone is the logical extension in order to make transition to a just and sustainable food system possible. Food scholars and activists need to connect food issues with Black Lives Matter, police and prison reform, healthcare, Indigenous peoples' "land back" movement and resistance to incursions on their land, affordable housing and other issues of injustice in our society so that we see the entangled intersections and build political power to make deep changes.

I want to go back and connect these three ways to push boundaries that I have used with the big challenges in the food system. First, learning more about agroecology from social movements that are fighting for its recognition has taught me that it is the agricultural system with the greatest potential to succeed where the technocratic industrialized food system has failed. We still don't know enough about how agroecology can perform best under different circumstances, nor how alternatives to capitalist markets and business structures need to intersect with it to best support growers. This is no surprise, given that most investment in research and development since the 1950s has bolstered the industrial food system; but agroecology can prevent the continued erosion of biodiversity, land and water quality. Second and third, avoiding future pandemics and restoring degraded land and waters will depend on adopting agroecological practices that build biodiversity and soil fertility, sequester carbon in the soil instead of releasing it to the atmosphere, and eschew toxic agrochemicals that end up in water supplies. The strongest advocates at present for agroecology are people from social movements, who see it as a means of survival, although growing numbers of academics are joining them. Fourth and fifth, fighting the forces that try to divide the progressive food movement and redistributing food system power so that everyone can achieve their human rights will be done best by working with social movements focused on human rights and through anti-racist practice. 
A few final words of advice for young scholars, from what I've learned:

- Be clear about who and what you want your work to serve. Be willing to walk away from a job that doesn't feed you or that undermines your integrity. The sooner you recognize this, the better-walking even farther on the wrong path gets you farther from where you need to go.

- Look at who is benefiting and who is paying the costs of food policies. Following the money is a good strategy, but also pay attention to health inequities. These are rampant in the US and unlikely to disappear until we vanquish White supremacy.

- Recognize that food is deeply political. Improving the life options for marginalized people by addressing violations of their rights will require building political strength through coalitions. Honor frontline activists and find the intersections between food issues and other manifestations of injustice in our society. Explore these through digging into feminist, Indigenous, critical race scholarship and other bodies of literature.

- Seek out international opportunities, even if they don't pay financially.

- And last, look beyond US borders and your own boundaries to learn how people are meeting challenges better, whether those are issues of food access, health, living more sustainably, or achieving human rights for all. The rest of the world has much to teach us.

\section{References}

Dudley, Nigel, and Sasha Alexander. 2017. Agriculture and biodiversity: a review. Biodiversity 18 (2-3): 45-49. https://doi. org/10.1080/14888386.2017.1351892.
Herren, Hans R., Benedikt Haerlin and the IAASTD+10 Advisory Group. 2020. Transformation of Our Food Systems: The Making of a New Paradigm. https://www.globalagriculture.org/filea dmin/files/weltagrarbericht/IAASTD-Buch/PDFBuch/BuchW ebTransformationFoodSystems.pdf

Intergovernmental Panel on Climate Change (IPCC). 2019. Climate Change and Land: an IPCC special report on climate change, desertification, land degradation, sustainable land management, food security, and greenhouse gas fluxes in terrestrial ecosystems. Edited by Shukla PR, Skea J, Calvo Buendia E, Masson-Delmotte V, Pörtner H-O, Roberts DC, Zhai P, Slade R, Connors S, van Diemen R, et al.

Mateo-Sagasta, Javier (IWMI), Sara Marjani Zadeh (FAO) and Hugh Turral. 2017. Water pollution from agriculture: a global review. Rome: Food and Agriculture Organization. http://www.fao. org/3/a-i7754e.pdf

Painter, Nell Irvin. 2011. The history of White people. New York: W.W. Norton \& Company.

Publisher's Note Springer Nature remains neutral with regard to jurisdictional claims in published maps and institutional affiliations.

Molly D. Anderson is the William R. Kenan Jr. Professor of Food Studies at Middlebury College in Vermont, where she directs the Academic Program in Food Studies and teaches courses including Agroecology, Food Power and Justice, Fixing the Food System and Food Policy. She is interested in multi-actor collaborations for sustainable food systems, food system resilience, human rights in the food system, the right to food in the US, and bridging interests and concerns of academicians and community-based activists. She works to improve food system sustainability at multiple scales, from the local to the international. She participates in Vermont's Farm to Plate Network; Food Solutions New England; the national Inter-Institutional Network for Food, Agriculture \& Sustainability; and the International Panel of Experts on Sustainable Food Systems (IPES-Food). She co-founded and directed the first five years of the Agriculture, Food \& Environment Graduate Degree Program at Tufts University's School of Nutrition Science \& Policy; served on the staff at Oxfam America; and consulted for local, state and international clients. She earned an interdisciplinary Ph.D. in Systems Ecology from the University of North Carolina at Chapel Hill. 